К. М. Ковальов, заступник директора,

Державний науково-дослідний експертно-

криміналістичний иентр МВС України, м. Київ

ORCID: https://orcid.org/0000-0003-1964-9283

\title{
ВИЗНАЧЕННЯ ДАВНОСТІ ВИГОТОВЛЕННЯ ДОКУМЕНТА: ІСТОРИЧНИЙ АСПЕКТ І СУЧАСНІ ТЕНДЕНЦІЇ
}

\begin{abstract}
Мета статті - виявити сучасні тенденції подальшого формування науково-методичних засад визначення давності виготовлення документа в контексті основних віх розвитку криміналістики. Методологія. Достовірність отриманих результатів і висновків забезпечено використанням комплексу загальнонаукових і спеціальних методів дослідження. Зокрема, за допомогою діалектичного методу як загального методу пізнання питання теми розглянуто в динаміці, виявлено їх взаємозв'язок і взаємообумовленість, завдяки застосуванню методів системного й історичного аналізу, формальної логіки, абстракції й аналогії, узагальнення й класифікації в контексті основних віх розвитку криміналістики окреслено етапи формування науково-методичних засад визначення давності виготовлення документа, схарактеризовано основні тенденції ïх удосконалення, виокремлено перспективні напрями розширення можливостей судової експертизи документів із метою визначення давності їх виготовлення. Наукова новизна. Зроблено спробу крізь призму історії стисло схарактеризувати сучасні тенденції формування науково-методичних засад визначення давності виготовлення документа в контексті основних віх розвитку криміналістики. Висновки. Виокремлено етапи розвитку криміналістичного документознавства, формування науково-методичних засад дослідження документів із метою визначення давності їх виготовлення, що умовно окреслені в контексті основних віх розвитку криміналістики трьома великими періодами: виникнення та формування основ криміналістичних знань (до кінця XIX ст.); становлення й розвиток криміналістики як науки (кінець XIX ст. - кінець 70-х рp. XX ст.); диференціація криміналістичних знань і формування в їі межах основ самостійних наукових дисциплін (від кінця 70-х рр. XX ст.). Наголошено, що на сучасному етапі розвитку криміналістичного документознавства дослідження, які проводяться з метою визначення давності виготовлення документа, спираються на грунтовний науково-методичний доробок щодо окремих реквізитів, насамперед виконаних пастами кулькових ручок, штемпельними фарбами, натомість науково-методичне забезпечення дослідження інших реквізитів і частин документа потребує поглибленого вивчення, практичної апробації, а також запровадження комплексного підходу і використання спеціальних знань, різних аналітичних і спеціальних методів криміналістичного дослідження документів, зокрема поєднання методів і методик вирішення завдань судової почеркознавчої експертизи і технічного дослідження документів. Виявлено перспективні напрями розширення можливостей судової експертизи документів із метою визначення давності їх виготовлення, якими, убачається, є: поглиблення їх комплексності; використання спеціальних знань, різних аналітичних і спеціальних методів криміналістичного дослідження документів; розвиток неруйнівних методів; автоматизація й комп'ютеризація процесів застосування методів; алгоритмізація процесів дослідження.

Ключові слова: криміналістичне документознавство; судова технічна експертиза документів; судова почеркознавча експертиза; визначення давності виготовлення документа; науково-методичні засади визначення давності виготовлення документа; методи дослідження; методика дослідження; комплексний підхід; спеціальні знання.
\end{abstract}

\section{Вступ}

Криміналістичне документознавство як галузь криміналістичної техніки становить систему знань, розділи якої (загальні положення криміналістичного документознавства; криміналістичне дослідження рукописів (письмового мовлення); криміналістичне дослідження рукописних текстів (почерку); техніко-криміналістичне дослідження документів) тісно пов'язані між собою і грунтуються на досягненнях природничих і технічних наук, законодавстві та спеціальних знаннях у галузі загального документознавства, інформатики, поліграфії, історії, хімії, фізики, анатомії, медицини, психології (Biriukov, Kovalenko, Biriukova, \& Kovalov, 2007).
У контексті нашого дослідження мають значення лише три складники цієї системи знань: загальні положення криміналістичного документознавства, криміналістичне дослідження рукописних текстів (почерку) і техніко-криміналістичне дослідження документів.

Теоретичне підгрунтя дослідження становлять насамперед праці таких видатних особистостей, як А. Бертільйон, Є. Ф. Буринський, А. Вейнгарт, Е. Локар, А. С. Осборн, О. О. Поповицький, С. М. Потапов, С. М. Трегубов та інших фахівців.

Проблеми криміналістичного документознавства вивчали, зокрема, Л. Ю. Ароцкер, Р. С. Бєлкін, А. І. Вінберг, В. Г. Гончаренко, I. В. Гора, О. О. Ейсман, Н. І. Клименко, В. О. Ко- 
новалова, Ю. Г. Корухов, В. К. Лисиченко, І. В. Пиріг, М. В. Салтевський, М. Я. Сегай, М. В. Терзієв, В. Ю. Шепітько, О. Р. Шляхов, М. Г. Щербаковський, М. П. Яблоков.

Останнім часом вітчизняні науковці плідно працюють, розглядаючи здебільшого теоретичні засади судової експертизи, як-от: основи почеркознавства (Dmytrenko, \& Zakhariiash, 2004); криміналістичне документознавство (Biriukov, Kovalenko, Biriukova, \& Kovalov, 2007); судово-почеркознавча експертиза (Melenevska, Svoboda, \& Shabotenko, 2007); теоретичні основи експертної діяльності органів внутрішніх справ (Pyrih, 2011); експертизи в судочинстві України (Honcharenko, \& Hora (Red.), 2015); теоретико-методологічні та праксеологічні засади судових експертиз у кримінальному процесі (Shcherbakovskyi, 2016); актуальні питання криміналістичного дослідження документів зі зміненим первинним змістом (Yudina, 2018); огляд документів під час розслідування злочинів у сфері оподаткування (Amelina, \& Kuzhilna, 2019); верифікація психодіагностичних можливостей рукописних текстів (Bocheliuk, Panov, \& Zaitseva, 2019); теоретичні й методичні основи експертизи давності документа (Stratonov, 2019, 2020a, 2020b); генезис криміналістичного дослідження документів як галузі криміналістичної техніки (Sezonov, 2020); історія виникнення, розвитку та становлення графологічної експертизи письма (судової почеркознавчої експертизи) (Khlivniak, 2020); напрями удосконалення науково-методичного забезпечення кримінологічної діяльності судово-експертних установ України (Filipenko, 2020); особливості експертизи старовинних книг (Peredrii, 2020).

Зарубіжні колеги висвітлюють такі, зокрема, питання: криміналістична експертиза підробки (Iarovenko, \& Atanova, 2013); криміналістична експертиза визначення відносної давності виконання реквізитів документів (Toropova, 2014); дослідження почерку низької загальної якості (Adhikari, Roy, Dasgupta, \& Pradhan, 2018); методи та прийоми наукової експертизи документів (Ellen, Day, \& Davies, 2018); графологічний аналіз та ідентифікація рукописних текстів (Mironovsky, Nikitin, Reshetnikova, \& Soloviev, 2018); експертиза документів колориметричним методом (Nikolaev, 2018); відновлення послідовності записів у сканованих рукописних текстах (Saparov, 2018); актуальні проблеми застосування методики визначення давності виконання реквізитів у документах за відносним вмістом у штрихах летких розчинників (Skoromnikova, Iurova, \& Stepanenko, 2018); хромато-мас-спектрометричний аналіз складу рукописних штрихів за природного та штучного старіння паперових документів (Baigildieva, 2019); розрізнення рукописних текстів і текстів, створених за допомогою комп'ютеpa (Hamasaki, Nakamura, Nitta, \& Babaguchi, 2019); розпізнавання друкованих та рукописних текстів (Sahare, \& Dhok, 2019); подібності в рукописних текстах (Balreira, Filho, \& Walter, 2020); судова експертиза документів у XXI ст. (Kelly, \& Angel (Eds.), 2020) та ін.

Проте сьогодні бракує системних досліджень і фундаментальних розробок теоретичних, організаційних і методичних підвалин криміналістичного документознавства в контексті генезису, сучасного стану і перспектив розвитку можливостей визначення давності виготовлення документа, удосконалення (а стосовно деяких напрямів й обгрунтування) науково-методичного забезпечення таких досліджень.

\section{Мета й завдання статті}

Мета статті - виявити сучасні тенденції подальшого формування науково-методичних засад визначення давності виготовлення документа в контексті основних віх розвитку криміналістики.

Для досягнення цієї мети потрібно виконати такі завдання:

виокремити етапи розвитку криміналістичного документознавства та формування науково-методичних засад дослідження документів із метою визначення давності їх виготовлення;

3'ясувати стан розробленості науково-методичних засад дослідження документів із метою визначення давності їх виготовлення;

виявити перспективні напрями розширення можливостей судової експертизи документів із метою визначення давності їх виготовлення.

\section{Виклад основного матеріалу}

Розвиток експертизи документів пов'язаний зі створенням першого документа.

3 формуванням державності документи постають самостійною системою директив, набуваючи специфічних рис. Так, закони вавилонського царя Хаммурапі - XVIII ст. до н. е., афінського архонта Драконта - VII ст. до н. е., індійські Закони Ману - I ст. до н. е., Варварські правди - кінець V початок VI ст. н. е., «Руська правда» - XI ст. н. е. являють собою перші (що дійшли до нас) офіційні законодавчі акти з урегулювання суспільних і майнових відносин громадян. Подальший розвиток документів (документальних відносин), 3 огляду на те, що вони впливають на юридичні факти й події, розширюють або обмежують певне коло прав і обов'язків, зумовив появу такого явища, як підроблення документів - виготовлення і використання різноманітних документів, зміст яких не відповідає дійсності. Отже, наголошують В. К. Лисиченко і В. В. Липовский, широке вико- 
ристання письмових документів супроводжувалося й різними їх підробленнями (Lisichenko, \& Lipovskii, 1990, s. 6).

Уперше про підроблення документів (здебільшого заповітів, договорів позики, інших, пов'язаних з отриманням матеріальної вигоди), а також особливих фахівців із почерку, які розпізнавали підроблення і виступали спеціалістами в судах (Krylov, 1963, s. 16), згадується у Стародавньому Римі.

Виявлення підроблення документів на професійній основі датується 1570 р., коли був започаткований окремий заклад (на зразок експертних установ) - паризька Корпорація «Experts en ecriture», працівники (обізнані особи) якої володіли спеціальними знаннями в галузі письма. Король Генрих IV 1595 р. надав їм звання присяжних майстрів - письмознавців із дослідження почерків, підписів, рахунків і розписок, що заперечуються в судовому порядку. Людовик XV 1727 р. перетворив цю Корпорацію на особливу академію. Після іiі ліквідації 1792 р. утворено Академію письма, до якої увійшли члени колишньої Корпорації, але напрям їх діяльності змінився (Terziev, \& Eisman, 1949, s. 34; Métayer, 1990).

Вихідною точкою формування науково-методичних засад судової експертизи документів можна вважати перші друковані видання Ф. Демеля (1604 р., Париж) і Ж. Равено (1665 р., також Париж). У своїй праці, що була видана тричі, Ф. Демель оприлюднив поради 3 розпізнавання підроблених рукописів, порівняння почерків і підписів для того, щоб уміти бачити і виявляти будь-які підроблення, з докладним і повним поясненням мистецтва письма, про те, як розпізнати й розшифрувати приховані і таємні письмена. Трактат про дослідження письма Ж. Равено став підручником, як тоді вважала судова влада, і для тих, хто підробляє документи. Тому 1670 р. за королівським наказом увесь наклад цієї праці прилюдно спалено перед будинком суду (Tregubov, 1915, s. 166; Uvarova, 2015, s. 160).

Документальні пам'ятки права надають можливість, зазирнувши в минуле, пізнати генезис дослідження документів. Так, наголошував Є. Ф. Буринський, від початку свого розвитку експертиза документів складається з двох основних розділів: судового почеркознавства та інших видів судового дослідження документів (Terziev, \& Eisman, 1949, s. 21).

Досліджуючи підроблені документи, які розглядалися судами, насамперед вивчали почерк, завдяки чому встановлювали (спростовували) факт підроблення. Зважаючи на те, що навичками рукопису найкраще володіли церковні особи, то першими експертами-почеркознавцями були дяки і піддячі. Вони детально досліджували рукопис, вивчали структуру букв, звіряли накреслення в досліджуваному тексті зі зразками почерку перевірюваних осіб (Krylov, 1963, s. 16-28).

Становлення сучасного почеркознавства як складника криміналістичного документознавства пов'язано 3 формуванням і розвитком системи ідентифікаційних ознак почерку за такими напрямами: каліграфічний, прикметоописовий, графометричний і графологічний

Каліграфія (краснопис) - галузь знань про формування красивого почерку, правильне виконання букв, слів. Каліграфічні дослідження доручалися каліграфам (фахівцям-почеркознавцям), які нібито володіли «таємницею» письма - секретарям, учителям каліграфії, художникам, а то й просто грамотним людям, обмежувалися встановленням зовнішньої подібності чи розбіжності почерків і не мали наукового підгрунтя (Piliukov, 2017 , s. 257-258), доволі часто спричиняли грубі помилки. 3 цього приводу Є. Ф. Буринський зазначав, що органам правопорядку доводилося боротися як із підроблювачами документів, так і 3 фантазією каліграфів (Krylov, 1987, s. 135).

Методику прикметоописового підходу в експертизі почерку розробив відомий французький криміналіст Альфонс Бертільйон, спираючись на засади, які він започаткував, використовуючи антропометрію для ідентифікації особи за розмірними характеристиками певних частин тіла й описом зовнішніх прикмет. Проте цей метод «не досліджував ознак із достатнім науковим обгрунтуванням, не встановлював закономірність ïх утворення, зумовленість анатомічних, фізіологічних та психологічних особливостей виконавця рукопису» (Piliukov, 2017, s. 258). Праця А. Бертільйона про порівняння почерку і графічну ідентифікацію, в якій «значна увага приділялась ознакам почерку та вперше, наскільки нам відомо, розкривалася методика криміналістичної ідентифікації особи за індивідуальними ознаками почерку» (Ishchenko, 2003, s. 82), побачила світ 1898 р. у Парижі.

Графометрія, що стала продовженням прикметоописового підходу, виникла на початку XX ст. і була спрямована на винайдення об'єктивних засобів дослідження почерку. Її творцем вважають Едмона Локара, який, грунтуючись на науковому доробку Персіфора Фразера, П’єра Гумбера, Едуарда Ружемона й інших дослідників, власному досвіді, дійшов висновку, що експертиза письмових документів, якщо ввести поняття розмірів, стає на шлях наукового дослідження, потребуючи переходу від якісного до кількісного: пізнати, наголошував він, - це виміряти (Lokar, 1941, s. 450-451). Йому належить і така теза: 
почерк є слідом, який залишають сукупності рухів тіла, зумовлені змінними та незмінними причинами (Lokar, 1941, s. 452). Певні напрацювання цього методу знайшли своє відображення в сучасних характеристиках загальних ознак почерку (розмір, розгін, розміщення, зв'язність та ін.). На території України графометрію вперше використав 1915 р. очільник Київського кабінету науково-судових експертиз С. М. Потапов (Krylov, 1980, s. 174).

Графологія - галузь знань про почерк і методи його дослідження з позиції відображення в ньому індивідуально-психічних особливостей людини, яка пише (Syniavskyi, \& Serhieienkova (Avt.-uklad.), 2007, s. 64). В Італіі 1622 р. надруковано роздуми К. Бальдо про способи пізнання вдачі й особливостей того, хто писав, за його письмом, можливості використання ознак почерку для характеристики особи. За допомогою відображення письмово-рухових навичок, які проявлялися в письмі, спеціалісти-графологи (зазвичай це були лікарі, юристи, священнослужителі та ін.) намагалися дати психологічну характеристику особі, яка писала текст.

Цих «обізнаних осіб» А. Бертільйон піддав нещадній критиці, наголосивши на тому, що їхні дослідження зводяться до нової галузі окультизму й можуть вважатися приємною грою чи забавкою, але не більше. За словами С. М. Трегубова, ці методи псевдонаукові і не мають жодної наукової цінності, їх застосування в судовій експертизі має бути рішуче відкинуто (Tregubov, 1915, s. 167).

На основі наукового аналізу описаних вище напрямів Є. Ф. Буринський узагальнив і систематизував наукові дані про почерк. Поглибив їх 1908 p. О. О. Поповицький, уперше класифікувавши використовувані для ідентифікації десять ознак почерку. Серед них найбільш стійкими були визнані відносна величина знаків та їх елементів, елементи зв'язку букв і накреслення певних літер, які в разі спроби змінити почерк залишаються незмінними. Грунтуючись на цих знаннях, завідувач Київського кабінету науково-судових експертиз С. М. Потапов розробив першу методику дослідження почерку, яку 1915 р. оприлюднив на з'їзі керівників кабінетів науково-судових установ.

Одночасно з рукописами проводилися наукові дослідження й документів.

Формуванням науково-методичних засад залучення спеціальних знань для дослідження документів можна вважати науково-практичний доробок Альфреда Наке та Персіфора Фразера. А. Наке у своїй праці із судової хімії 1874 р. 3-поміж питань, пов'язаних із виявленням отруйних речовин, вивченням слідів і обставин застосування вогнепальної зброї, підробленням сплавів монет тощо, схематично висвітлив відомі автору способи підроблення документів і методи їх ви- явлення. П. Фразер у посібнику з вивчення документів із метою установлення індивідуального характеру почерку, шахрайства та підроблення, виданому 1894 р. у США, запропонував кілька нових методів дослідження.

На початку XX ст. із розвитком фізики, хімії та фотографії посилилась науковість криміналістичного дослідження документів і розширились можливості експертних досліджень документів загалом та у визначенні давності зокрема. Цьому сприяло й видання посібника із судової фотографiï (Paul, 1900) у Берліні, а також історико-догматичного дослідження «Подлогъ документовъ» (Zhizhilenko, 1900) у Санкт-Петербурзі, у якому O. О. Жижиленко запропонував доктрину про підроблення як про злочин і визначив його сутність, проаналізував підроблення документів згідно з правом Російської імперії.

Великий внесок у криміналістичне дослідження документів, передусім у практику виявлення й фіксування видалених текстів, зробив Є. Ф. Буринський. Він став каталізатором виникнення нового напряму в судовій фотографії. Розроблений ним метод фотографічного посилення контрастів кольороподілу дозволив розширити можливості виявлення видалених чи знебарвлених записів у документах. Цим способом Є. Ф. Буринському вдалося виявити тексти на найдавніших шкіряних грамотах, знайдених під час розкопок на території Московського кремля.

У своїх працях, насамперед у головному фундаментальну доробку «Судебная экспертиза документов, производство ее и пользование ею» (Burinskii, 1903), учений уперше описав прийоми i методи виявлення підроблення документів, висвітлив можливості використання фізичних, фотографічних, хімічних і фізико-хімічних методів під час дослідження документів, зокрема й для визначення їх давності (віку) (Lisichenko, \& Lipovskii, 1990).

У США 1910 р. А. С. Осборн видає монографію, у якій досліджує документи, що викликають сумніви, і висвітлює окремі можливості визначення давності документа.

С. М. Трегубов 1915 р. публікує практичне керівництво для судових слідчих «Основы судебной техники. Научно-технические приемы расследования преступлений» (Tregubov, 1915), у якому описує способи підроблення документів, методи ix виявлення, які, зокрема, можуть бути використані й для визначення давності документа.

За безпосередньою участю вченого-криміналіста професора С. М. Потапова 1932 р. друкується оброблений переклад праці А. С. Осборна «Техника исследования документов» (Osborn, 1932), у якій також запропоновано методи дослідження документів, пов'язані з визначенням їх давності. 
При цьому, наголошуючи на високому професійному рівні розроблення проблеми та доступності матеріалу, професор зазначає, що цей доробок стане у пригоді експертам, оскільки в царині дослідження документів і почерку не має такого доволі систематизованого керівного посібника (Potapov, 1932).

У наступні роки найбільш вагомий внесок у формування наукових підвалин, розроблення методів і методики дослідження документів зробили А. І. Вінберг, О. Ю. Брайчевська, О. О. Ейсман, М. М. Зюскін, Б. Р. Киричинський, Н. І. Клименко, В. В. Липовський, В. К. Лисиченко, 3. С. Меленевська, М. Я. Сегай, М. В. Терзієв. Реалізація наукового доробку фахівців дозволила удосконалити можливості фізичних, фізико-хімічних і фотографічних методів у криміналістиці, застосовуючи їх під час дослідження документів.

Так, у 1947 р. О. О. Ейсман запропонував спосіб, який значною мірою спрощував метод кольороподілу. Замість складання кількох шарів із негативними зображеннями досліджуваного документа він рекомендував суміщати (накладати) значну кількість шарів негативних зображень за допомогою проєктора, який отримав назву оптичного мультиплікатора (Eisman, 1947; Krylov, 2020).

Проблеми посилення контрасту фотографічних зображень багато років вивчали М. М. Зюскін та О. Ю. Брайчевська (Ziuskin, \& Kirichinskii (Red.), 1962; Braichevskaia, \& Ziuskin, 1967). Розроблені М. М. Зюскіним методи посилення фотографічних знімків знайшли своє застосування не лише в технічній експертизі документів, а й під час фотографування об'єктів із космосу. Напрацювання О. Ю. Брайчевської, що дозволили вирішувати питання хронологічної послідовності виконання штрихів, які перетинаються, уможливили розв'язання окремих завдань із визначення давності виготовлення документів.

Набули вдосконалення методи дослідження документів в ультрафіолетових, інфрачервоних, рентгенівських і радіоактивних променях. Зокрема, Б. Р. Киричинський запропонував методику встановлення збігів або розбіжностей у зразках паперу, олівців, чорнил тощо фотометричним вимірюванням в інфрачервоних променях за допомогою термоелектричного індикатора «Термощуп».

Можливості технічної експертизи документів суттєво розширились завдяки працям С. П. Мітрічева (використання емісійного спектрального аналізу), подружжя Кірліан (1949 р. на метод «високочастотної фотографії» вони отримали авторське свідоцтво, але про результати своїх експериментів повідомили вперше 1958 р.), В. К. Лисиченка (застосування радіоактивних ізотопів) і спеціальному обладнанню, що дозво- лило отримувати високоякісні фотознімки досліджуваних об'єктів, яке створили криміналісти О. Ф. Аубакіров і М. 3. Гатов (Mitrichev, 1939; Kirlian, \& Kirlian, 2003a, 2003b; Lisichenko, 1960; Aubakirov, 1965; Gatov, 1975).

Вагомий внесок у дослідження документів, виготовлених за допомогою знакодрукувальних пристроїв із літерною та мозаїчною будовою, зробила експерт Київського науково-дослідного інституту судових експертиз В. М. Палій. Вона окреслила, систематизувала й узагальнила ознаки, що характеризують кожний вид такого пристрою, та сформувала науково-методичні засади ідентифікаційних і діагностичних досліджень цих пристроїв, які також можуть використовувати експерти під час вирішення питань про давність виготовлення документа (Palii, 1989).

Знайшли своє застосування і лазерні методи дослідження, завдяки чому значно підвищилась ефективність дослідження документів із метою встановлення змісту видалених і згаслих текстів, послідовності нанесення штрихів, що перетинаються, визначення давності виконання документа.

Проте і сьогодні завдання, що полягає у з'ясуванні, чи не є документ підробленим, а якщо так, то хто його підробив, залишається, як багато років тому констатував Альберт Вейнгарт (Veingart, 1912 , s. 196), головним під час дослідження документів.

Поділяючи думку А. Вейнгарта, С. М. Трегубов вирізняє такі основні запитання, вирішувані судовою технічною експертизою документів від 1570-1665 рр.: Чи дійсного походження штемпелі і печатки та інші позначення на документі? У механічний чи хімічний спосіб знищено частину або весь текст документа, чи не замінювалися ці частини новими? Одним чи різними чорнилами виконані всі частині документа? У той самий чи різний час виконано весь текст документа і всі його частини? (Tregubov, 1915, s. 169).

При цьому запитання щодо визначення давності виготовлення документа не лише не втратило актуальності, а й, навпаки, постало чи не першим завданням технічного дослідження документів. Для його вирішення ще багато століть тому залучалися обізнані особи, а на більш пізньому етапі розвитку суспільства та науки криміналістики - професійні науковці й судові експерти-практики.

А втім, стверджував Є. Ф. Буринський, наприкінці IXX ст. жодна галузь судової експертизи не перебувала в такому дитячому стані, як експертиза підроблених документів (Burinskii, 1903).

3 цього часу формуються перші наукові методи виявлення підроблення документів - аналіз та порівняння. 
Послуговуючись цими методами, ілюструє А. Вейнгарт, обізнані особи довели підроблення родовідної дворянського походження певної особи від Адама М., що помер 1745 р., тобто за п'ять років до їі народження, i, відповідно, заповіту, у якому зазначено ім'я та прізвище співспадкоємця, який на дату його складання ще не народився, при цьому встановивши, що папір і чорнило, застосовувані для його виготовлення, пізнішого за дату на документі походження, а для підтвердження справжності складеного до 1874 р. документа використовувалася марка, уведена в обіг 1874 р. (Veingart, 1912, s. 201).

Інший приклад, наведений А. Вейнгартом, засвідчує актуальність позиції вченого-криміналіста Ієремія Бентама, що полягає у недовірі копіям документів і неможливості їх дослідження без оригіналу.

Так, за 10 років, від 1890 до 1900, дехто М. Алоїз у Празі виготовив, зазначає А. Вейнгарт, цілу купу підроблених дворянських дипломів. Він вишукував в архівах і церквах старі документи про народження, вінчання або смерть і вносив неправдиві записи в метричні або актові книги, при цьому використовував бліде чорнило та загострені за старинним зразком пір'я і намагався скопіювати старий переповнений завитками почерк. 3 цих фальшивих копій на його вимогу робили засвідчені копії, потрібні для доказу дворянського походження своїх клієнтів (Veingart, 1912, s. 198).

Основні причини недовіри, які висуває I. Бентам, такі: копія може не мати оригіналу або відрізнятися від нього випадково чи внаслідок підроблення; коли є оригінал документа, він може бути підроблений у цілому або мати навмисні зміни, при цьому в документі, який видається за оригінал, можна виявити ознаки підроблення, що не наявні в копії; якщо копію визнано оригіналом, а сам оригінал підробленого чи зміненого документа знищено, обман може бути не виявлений (Bentam, 1876, s. 235-236). Тобто дослідженню має підлягати лише оригінал документа. Підтвердженням цього $є$ історичні факти, описані А. Вейнгардом і С. Н. Трегубовим: досліджуючи датовану 1868 р. копію заповіту, було встановлено, що папір, на якому виготовлено цю копію, має фабричний знак орла Німецької імперії, що друкувався після 1870 p. (Veingart, 1912, s. 203); дуже якісно підроблений заповіт виявлено під час візуального дослідження водяного знаку на папері, папір із таким водяним знаком уведений в обіг 1908 р., а копію заповіту датовано 1905 р. (Tregubov, 1915, s. 210).

Методи аналізу та порівняння також застосовували, визначаючи давність виготовлення документа, коли вивчали печатки. А. Вейнгадр радив експертам, які досліджували цей реквізит, зверта- ти увагу на будову печатки, дату нанесення через можливість іiі перенесення 3 іншого документа або використання більш нової за дату документа (Veingart, 1912, s. 203).

Подальший розвиток хімічної науки дозволяє застосовувати поряд із зазначеними й новий метод дослідження документів - хімічний. Проте, наголошує А. Вейнгадр, піддавати хімічному впливу документ, вирішуючи питання достовірності, можна лише після вивчення його змісту, виду, властивостей паперу, почерку та підпису, адже діяльність хіміка призводить до руйнування його окремих частин (Veingart, 1912, s. 196).

Застосування знань хіміків дало поштовх до подальшого розвитку експертизи документів, зокрема й щодо визначення давності.

Так, вивчаючи штрихи тексту на папері, коли вирішується питання, чи відповідає зовнішній вигляд документа часу його написання, фахівці (Veingart, 1912, s. 202) окреслили ознаки виконання тексту в різний період часу: якщо текст написаний давно, навколо літер формуються жовтуваті кружечки, їх відсутність узагалі або навколо окремих літер чи знаків засвідчує, що цей документ або окремі його частини написані пізніше. Крім того, можливості хімічного методу дослідження документів поширили й на дослідження паперу. Як ознаки застосовували такі властивості паперу: упродовж певного часу папір жовтіє, з цього випливає, що коли по краях документа колір однаковий, то документ не піддавався змінам, але якщо колір країв відрізняється від кольору документа, то від нього відрізали певну частину. При цьому для імітації зміни кольору підроблювачі окурювали чи обливали папір кавою. Але якщо замочити папір, він стане білий.

Завдяки зусиллям Є. Ф. Буринського від 1889 р. застосовується фотографічний і мікроскопічний методи дослідження, слугуючи науково-технічними засадами технічної експертизи документів, що дозволяє вирішувати питання, які найчастіше постають стосовно часу написання документа, тобто встановлювати, що написано раніше, а що пізніше.

Розв'язання цього завдання грунтувалося на властивостях твердої частини фарбової речовини залишатися на поверхні паперу, а рідкої проникати в його товщу. Раніше в чорнилах як компонент застосовувалися солі заліза, що, згодом розширюючись, формували навколо літер жовту кайму. За допомогою мікрофотограми в літери, нанесеної менш як рік тому, на відміну від нанесеної понад рік, можна спостерігати чітку границю між білим папером і їі чорним тлом (Burinskii, 1903, s. 353).

Залучаючи висококваліфікованих фахівців у галузі хіміі, фізики, фотографії, зауважував Ганс 
Гросс у своїй праці «Руководство к расследованию преступлений» (Gross, 1930), доволі часто можна встановити точну або відносну давність документа. Крім того, з поширенням друкарських машин можливості для визначення давності документа значно зросли. Завдяки дослідженням, що здійснили криміналісти, окреслено ознаки, за якими можна встановити машину, на якій друкувався документ, виконавця тексту документа та період часу, у який виготовлений документ.

Першу спробу звернути увагу на необхідність комплексного підходу до дослідження документа з метою визначення давності його виготовлення зробила 1958 р. С. Ш. Касімова у праці «Определенение возраста документа (Из практики криминалистических исследований)». 3 iii погляду, зокрема, вік документа встановлюється всебічним дослідженням його особливостей із застосуванням графічних, фотографічних, мікроскопічних, хімічних та інших методів дослідження. Вивченню підлягають: зміст документа, орфографія, стиль викладення та розміщення окремих частин у документі; почерк, машинописний і друкарські шрифти; структура, склад і стан штрихів, паперу, клею та інших матеріалів, використовуваних для виготовлення документа (Kasimova, 1958, s. 3-6).

На комплексному підході наголошував М. В. Терзієв у навчальному посібнику «Криминалистическое исследование документов», коли зауважував, що давність документа визначають, вивчаючи зміст документа, матеріали і засоби письма, а також почерк (Terziev, 1966, s. 36-38).

Наступний (від 80-90 рр. минулого століття) етап розвитку експертизи документів у частині вирішення питання про давність виготовлення документа характеризується спрямуванням зусиль на розроблення та впровадження в діяльність науково-практичних і методичних напрацювань, присвячених застосуванню хімічних або фізико-хімічних методів дослідження фарбових матеріалів, якими виконано окремі реквізити документа.

У цьому напрямі працювали вчені і практики, досліджуючи, зокрема, питання, пов'язані із судовою експертизою чорнила і паперу (Brunelle, \& Reed, 1984); визначенням віку чорнила кулькової ручки через порівняння летких компонентів (Stewart, 1985); установленням факту невідповідності віку рукописних записів, виконаних кульковими ручками, даті, зазначеній у документi (Batygina, Bezhanishvili, Orekhova, \& Trosman, 1993); визначенням віку чорнила кулькової ручки методом газової та денситометричної тонкошарової хроматографії (Aginsky, 1994); можливістю визначення віку відбитків печаток і штампів за змістом у штрихах летких компонентів (Bezhanishvili, Batygina, \& Trosman, 1998) та ін. У результаті ок- реслено ознаки штучного старіння документів, визначено методи та підходи до можливості дослідження паст кулькових ручок із метою встановлення часу виконання записів і підписів тощо.

На підставі цього сформовано два підходи (дослідження окремих компонентів (розчинників) паст кулькових ручок - фенілгліколю та штемпельних фарб і чорнил - гліцерину та води), зумовлені здатністю розчинників упродовж певного часу зменшувати свою концентрацію завдяки випаруванню. Використання газових хроматографів для вирішення цих завдань дозволило створити науково-методичні засади проведення таких досліджень.

Антонио Канту (Cantu, 1995a, 1995b), а згодом В. Н. Агінський (Aginsky, 1996) започаткували метод визначення вікових змін безбарвних летких компонентів (розчинників) паст, штемпельних фарб, гелевого чорнила, заснований на екстракції i прискореному старінні штрихів із метою вилучення з нього залишкових кількостей розчинника. В. Н. Агінський запропонував досліджувати ступінь полімеризації пасти із застосуванням хроматографа з мас-спектрографічним детектором, визначаючи співвідношення кількості фенілгліколю, вилученого зі штриха слабким екстрагентом, до кількості фенілгліколю, вилученого з того самого штриха сильним екстрагентом (Aginskii, 1997).

У цьому напрямі працюють, зокрема, й фахівці наукових і науково-дослідних інститутів Австралії, Італії, Німеччини та інших країн (Digital Technology, 2006).

Крім того, початок XXI ст. означився зосередженням уваги на вдосконаленні наявних науково-методичних підходів і визначенні можливостей застосовувати інші методи дослідження. Так, для вирішення питання давності нанесення штрихів кульковою ручкою італійські фахівці запропонували застосовувати метод визначення концентрації радіовуглецю в папері (Zavattaro, Quarta, D'Elia, \& Calcagnile, 2007).

Для визначення віку фарбової речовини кулькової ручки німецкі колеги (Bügler, Buchner, \& Dallmayer, 2008) започаткували два підходи, що полягають у прямому та непрямому датуванні. Пряме базується на термічному аналізі фарбових матеріалів із застосуванням хромато-мас-спектрометрії, яким визначається кількість розчинника, що екстрагується з фарбової речовини за низьких температур, який зі збільшенням проміжку часу перебування на папері зменшується. За непрямого датування досліджувана фарбова речовина порівнюється з достовірними зразками еталонної колекції.

Вирішуючи питання давності виготовлення документів, провідний фахівець Київського 
НДІСЕ О. В. Цимбал (Tcymbal, 2013) удосконалив науково-методичні підходи до визначення абсолютної давності документа із застосуванням газової хроматоргафії, досліджуючи кількісні та якісні характеристики фарбових речовин кулькових ручок, штемпельних фарб, чорнил для струминних принтерів із подальшим визначенням ідентифікаційних ознак їх рецептур.

Можливості застосування газової хромато-мас-спектрометрії для з'ясування давності нанесення реквізитів документів, виконаних кульковою ручкою, розширили єгипетські колеги, визначаючи концентрацію розчинника через коефіцієнт його леткості (EL-Sabbah, Gomaa, El-Hefny, \& Al-Hawary, 2019). Аналогічний напрям удосконалюють і фахівці Російського федерального центру судової експертизи при МЮ РФ (Skoromnikova, Iurova, \& Stepanenko, 2018), вирішуючи питання щодо давності виконання реквізитів документа з вивченням відносного вмісту у штрихах летких розчинників.

Починаючи 32013 р. експерти-практики та науковці багатьох країн світу розпочали випробування можливостей застосування раманівської спектроскопії. Російські фахівці найбільш детально описали методологічні підходи до їі застосування під час дослідження документа для визначення його давності і штучного старіння (Grechukha, Gorshkova, Panov, Tumkin, Kirillova, Lukianov, Kirillova, \& Kochemirovsky, 2017), а також установлення факту штучного старіння документа під впливом підвищених температур із використанням побутових приладів за допомогою методу рідинної хроматографії з мас-спектрометричним детектуванням (Baigildieva, Baigildiev, Shpigun, \& Rodin, 2019).

Отже, сьогодні діяльність фахівців здебільшого зосереджена на дослідженні окремих реквізитів документа, у тому числі фарбових матеріалів і паперу.

Утім, C. I. Мотря підготував методичні рекомендації щодо визначення давності виконання підписів із застосуванням традиційних криміналістичних методів (Motria, 2005). Їх практичний аспект поглибила О. Г. Гуліна (Gulina, 2007) і згодом (2012 р.) розробила методику встановлення часу виконання підпису в документі методами судової почеркознавчої експертизи, запропонувавши використовувати якісно-описовий і кількісний методи почеркознавчої експертизи, а також застосовувати методи діагностичного та ідентифікаційного дослідження, насамперед вивчаючи загальні та окремі ознаки підпису, при їх віднесенні до окремих проміжків часу виникнення або зникнення, зважаючи на дату виготовлення документів (Gulina, 2017).
За розробленою Державним науково-дослідним експертно-криміналістичним центром МВС України (Kovalov, \& Kovalenko (Uklad.), 2009) методикою 3 дослідження відбитків печаток і штампів, оцінюючи сукупність виявлених загальних та окремих ознак, що відобразилися у відбитках, можна визначити період часу, у який їх нанесено на документ, унаслідок чого встановити часовий період, у який виготовлено сам документ.

Сьогодні науковці і практики вивчають можливість застосування ще одного методу дослідження реквізитів документів, а саме штрихів, виконаних барвною речовиною, через визначення часу, потрібного для проникнення барвника в товщу паперу та його розтікання периметром штрихів на поверхні паперу (Kovalov, Dovbii, Hres, \& Bychkov, 2020).

Доробок фахівців із різних напрямів дослідження документів із залученням спеціальних знань, а також такий, що спрямований на застосування комплексного дослідження окремих складових i реквізитів документа, розширює можливості визначення давності їх виготовлення. Позитивний приклад застосування такого підходу - результат діяльності судових експертів науково-дослідного інституту поліції Швейцарії, які комплексним дослідженням, вивчаючи документи 3 метою визначення дати їх походження, застосовуючи різноманітні методи з дослідження почерку та підписів, паперу, способів нанесення тексту, будови шрифтів, складу фарбових матеріалів тощо, обгрунтовано встановили, що наданий на дослідження «щоденник Гітлера» підроблений. Коли його підробляли, використовували клей $\mathrm{i}$ нитки для скріплення книжкових блоків, які виготовлялися після 1945 р. Крім того, документ про засвідчення певного юридичного факту був створений не в рік, яким він датований, а на 20 років пізніше. До того ж акції підприємства, датовані 1960 р., були виготовлені на бланку, що містить водяний знак, який почали наносити лише в 1961 p., а підписи в них виконані в період 1973-1974 pp. (Digital Technology, 2006).

Отже, формування науково-методичних засад визначення давності виготовлення документа слід розглядати в контексті основних віх розвитку криміналістики, які А. В. Іщенко умовно окреслив трьома великими періодами (Ishchenko, 2003, s. 44).

Ідучи цією логікою, зробимо спробу крізь призму історії стисло схарактеризувати сучасні тенденції формування науково-методичних засад визначення давності виготовлення документа.

Перший період - виникнення та формування основ криміналістичних знань (до кіния XIX cm.):

зародження елементів криміналістичних знань - охоплює процеси (до кіния XVII cm.), коли 
офіційно юридично визнано необхідність проведення експертиз, зокрема: створення першого документа; перше згадування про підроблення документів у Стародавньому Римі; на професійній основі (із залученням обізнаних осіб, які володіли спеціальними знаннями в галузі письма) виявлено підроблення документів; перші друковані видання як вихідна точка формування науково-методичних засад судової експертизи документів;

формування основ криміналістичних знань (XVIII - кінець XIX cm.): започаткування системи ідентифікаційних ознак почерку за такими напрямами: каліграфічний, прикметоописовий, графометричний i графологічний; формування науково-методичних засад залучення спеціальних знань для дослідження документів; перші наукові методи виявлення підроблення документів - аналіз та порівняння.

Другий період - становлення та розвиток криміналістики як науки (кінець ХІХ ст. - кінець 70-х рp. XX cm.):

утворення системи криміналістичних знань (кінець XIX ст. - кінець 30-х рр. XX ст.): з розвитком фізики, хімії та фотографії посилилась науковість криміналістичного дослідження документів і розширились можливості експертних досліджень документів загалом та щодо визначення давності зокрема; від 1889 р. під час проведення експертизи документів застосовується фотографічний і мікроскопічний методи дослідження, що слугують науково-технічними засадами технічної експертизи документів, дозволяючи вирішувати питання, які найчастіше постають щодо часу написання документа, тобто встановлювати, що написано раніше, а що пізніше; Є. Ф. Буринський розробив метод фотографічного посилення контрастів кольороподілу, який дозволив розширити можливості виявлення видалених чи знебарвлених записів у документах, уперше описав прийоми і методи виявлення підроблення документів, висвітлив можливості використання фізичних, фотографічних, хімічних і фізико-хімічних методів під час дослідження документів, зокрема й для визначення їх давності (віку), узагальнив і систематизував наукові дані про почерк; поглибив їх 1908 р. О. О. Поповицький, уперше класифікувавши використовувані для ідентифікації десять ознак почерку; 1910 р. А. С. Осборн видає монографію, у якій досліджує документи, що викликають сумніви, і висвітлює окремі можливості визначення давності документа; С. М. Потапов розробив першу методику дослідження почерку, яку оприлюднив 1915 р.; С. М. Трегубов 1915 р. описує способи підроблення документів, методи їх виявлення, зокрема й що можуть бути використані для визначення давності документа; розвиток криміналістичної науки як самостійної системи знань (від 30-х рр. ХХ сm. - кінецьь 70-х pp. XX cm): О. О. Ейсман запропонував спосіб, який значною мірою спрощував метод кольороподілу; розроблені М. М. Зюскіним методи посилення фотографічних знімків знайшли своє застосування не лише в технічній експертизі документів, а й під час фотографування об'єктів із космосу; напрацювання О. Ю. Брайчевської дозволили вирішувати питання хронологічної послідовності виконання штрихів, які перетинаються, що відкрило можливість вирішувати окремі завдання з визначення давності виготовлення документів; набули вдосконалення методи дослідження документів в ультрафіолетових, інфрачервоних, рентгенівських i радіоактивних променях; Б. Р. Киричинський запропонував методику встановлення збігів або розбіжностей у зразках паперу, олівців, чорнил тощо, застосовуючи фотометричні вимірювання в інфрачервоних променях, за допомогою термоелектричного індикатора; можливості технічної експертизи документів суттєво розширились завдяки працям С. П. Мітрічева (використання емісійного спектрального аналізу), подружжя Кірліан (метод «високочастотної фотографії), В. К. Лисиченка (застосування радіоактивних ізотопів) і спеціальному обладнанню, яке створили криміналісти О. Ф. Аубакіров і М. З. Гатов, що дозволило отримувати високоякісні фотознімки досліджуваних об'єктів; перша спроба (С. Ш. Касімова, 1958 р.) звернути увагу на необхідність комплексного підходу до дослідження документа, при цьому, зокрема, наголошувалося, що вік документа визначається всебічним дослідженням його особливостей із застосуванням графічних, фотографічних, мікроскопічних, хімічних та інших методів дослідження. Вивченню підлягають: зміст документа, орфографія, стиль викладення та розміщення окремих частин у документі; почерк, машинописний і друкарські шрифти; структура, склад і стан штрихів, паперу, клею та інших матеріалів, використовуваних для виготовлення документа; на комплексному підході наголошував М. В. Терзієв.

третій період - диференціація криміналістичних знань та формування в ії межах основ самостійних наукових дисииплін (від кіния 70-х рр. $X X$ cm.): В. М. Палій окреслила, систематизувала й узагальнила ознаки, що характеризують знакодрукувальні пристрої з літерною та мозаїчною будовою і сформувала науково-методичні засади ідентифікаційних і діагностичних досліджень цих пристроїв, які також можуть використовувати експерти під час вирішення питань про давність виготовлення документа; знайшли своє застосування лазерні методи дослідження, завдяки чому 
значно підвищилась ефективність дослідження документів із метою встановлення змісту видалених і згаслих текстів, послідовності нанесення штрихів, що перетинаються, та давності виконання документа; спрямовувалися зусилля на розроблення та впровадження в діяльність науково-практичних і методичних напрацювань, присвячених застосуванню хімічних або фізико-хімічних методів дослідження фарбових матеріалів, якими виконано окремі реквізити документа; Антонио Канту, а згодом В. Н. Агінський започаткували метод визначення вікових змін безбарвних летких компонентів (розчинників) паст, штемпельних фарб, гелевого чорнила, заснований на екстракції і прискореному старінні штрихів із метою вилучення з нього залишкових кількостей розчинника; В. Н. Агінський запропонував досліджувати ступінь полімеризації пасти iз застосуванням хроматографа з мас-спектрографічним детектором, визначаючи співвідношення кількості фенілгліколю, вилученого зі штриха слабким екстрагентом, до кількості фенілгліколю, вилученого з того самого штриха сильним екстрагентом; зосередження уваги на вдосконаленні наявних методичних підходів і визначенні можливостей застосування інших методів; О. В. Цимбал (2013 р.) удосконалив науково-методичні підходи до визначення абсолютної давності документа із застосуванням газової хроматоргафії, досліджуючи кількісні та якісні характеристики фарбових речовин кулькових ручок, штемпельних фарб, чорнил для струминних принтерів із подальшим визначенням ідентифікаційних ознак їх рецептур; розширено можливості застосування газової хромато-мас-спектрометрії для з'ясування давності нанесення реквізитів документів, виконаних кульковою ручкою; розпочато випробування можливостей застосування раманівської спектроскопії, описано методологічні підходи до їі застосування під час дослідження документа для визначення його давності і штучного старіння, а також установлення факту штучного старіння документа під впливом підвищених температур із використанням побутових приладів за допомогою методу рідинної хроматографії з мас-спектрометричним детектуванням; підготовлено методичні рекомендації щодо визначення давності виконання підписів із застосуванням традиційних криміналістичних методів; розроблено методику встановлення часу виконання підпису в документі методами судової почеркознавчої експертизи, запропоновано використовувати якісно-описовий і кількісний методи почеркознавчої експертизи, а також застосовувати методи діагностичного та ідентифікаційного дослідження, особливо коли вивчаються загальні та окремі ознаки підпису, під час їх від- несення до окремих проміжків часу виникнення або зникнення, зважаючи на дату виготовлення документів; запропоновано методику технічної експертизи відбитків печаток і штампів, відповідно до якої, оцінюючи сукупність виявлених загальних та окремих ознак, що відобразилися у відбитках, можна визначити період часу, у який їх нанесено на документ, унаслідок чого встановити часовий період, у який виготовлено сам документ; опрацьовуються й інші методи, серед них дослідження реквізитів документів, а саме штрихів, виконаних барвною речовиною, через визначення часу, потрібного для проникнення барвника в товщу паперу та його розтікання периметром штрихів на поверхні паперу.

На часі спрямування зусиль на подальший розвиток науково-методичного супроводження комплексного підходу до вирішення завдань щодо визначення давності виконання документів - чи не найперспективнішого напряму розширення можливостей судової експертизи, а також автоматизація й комп’ютеризація процесів застосування методів, алгоритмізація процесів дослідження.

\section{Наукова новизна}

Зроблено спробу крізь призму історії стисло схарактеризувати сучасні тенденції формування науково-методичних засад визначення давності виготовлення документа в контексті основних віх розвитку криміналістики.

\section{Висновки}

1. Виокремлено етапи розвитку криміналістичного документознавства, формування науково-методичних засад дослідження документів із метою визначення давності ї виготовлення, що умовно окреслені в контексті основних віх розвитку криміналістики трьома великими періодами: виникнення та формування основ криміналістичних знань (до кінця ХIX ст.); становлення й розвиток криміналістики як науки (кінець XIX ст. - кінець 70-х рр. XX ст.); диференціація криміналістичних знань і формування в їі межах основ самостійних наукових дисциплін (від кінця 70-х рр. ХХ ст.).

2. Наголошено, що на сучасному етапі розвитку криміналістичного документознавства дослідження, які проводяться з метою визначення давності виготовлення документа, спираються на грунтовний науково-методичний доробок щодо окремих реквізитів, насамперед виконаних пастами кулькових ручок, штемпельними фарбами, натомість науково-методичне забезпечення дослідження інших реквізитів і частин документа потребує поглибленого вивчення, практичної апробації, а також запровадження комплексного 
підходу і використання спеціальних знань, різних аналітичних і спеціальних методів криміналістичного дослідження документів, зокрема поєднання методів і методик вирішення завдань судової почеркознавчої експертизи і технічного дослідження документів.

3. Виявлено перспективні напрями розширення можливостей судової експертизи документів із метою визначення давності їх виготовлення, якими, убачається, є: поглиблення їх комплексності; використання спеціальних знань, різних аналітичних і спеціальних методів криміналістичного дослідження документів; розвиток неруйнівних методів; автоматизація й комп'ютеризація процесів застосування методів; алгоритмізація процесів дослідження.

\section{References}

Adhikari, G., Roy, S., Dasgupta, T., \& Pradhan, T. (2018). A Novel Technique for Unwarping Curved Handwritten Texts Using Mathematical Morphology and Piecewise Affine Transformation. 2018 9th International Conference on Computing, Communication and Networking Technologies (ICCCNT), 1-7. DOI: https://doi.org/10.1109/ICCCNT.2018.8493881.

Aginsky, V. N. (1994). Determination of the age of ballpoint pen ink by gas and densitometric thin-layer chromatography. Journal of Chromatography A, 678, 119-125. DOI: https://doi.org/10.1016/0021-9673(94)87081-0.

Aginsky, V. N. (1996). Dating and Characterizing Writing, Stamp Pad and Jet Printer Inks by Gas Chromatography/Mass Spectrometry. Int. Journal of Forensic Documents Examiners, 2 (3), 103-116.

Aginskii, V. N. (1997). Ustanovlenie davnosti vypolneniia shtrikhov rukopisnykh tekstov: metod. rekomendatcii. M.: EKTc MVD Rossii. 6, [3] s. [in Russian].

Amelina, A. S., \& Kuzhilna, A. B. (2019). Ohliad dokumentiv pry rozsliduvanni zlochyniv u sferi opodatkuvannia. Yurydychnyi naukovyi elektronnyi zhurnal, 6, 362-365 [in Ukrainian]. DOI: https://doi.org/10.32782/2524-0374/2019-6/86.

Aubakirov, A. F. (1965). Ispolzovanie effekta vysokochastotnogo iskrovogo razriada pri tekhnicheskom issledovanii dokumentov. Problemy kriminalistiki i sudebnoi ekspertizy. Alma-Ata, 152-154 [in Russian].

Baigildieva, D. I. (2019). Khromato-mass-spektrometricheskii analiz sostava rukopisnykh shtrikhov pri estestvennom $i$ iskusstvennom starenii bumazhnykh dokumentov. (Avtoref. dis. kand. khim. nauk). Moskovskii gosudarstvennyi universitet imeni M. V. Lomonosova, M. 26 s. [in Russian].

Baigildieva, D. I., Baigildiev, T. M., Shpigun, O. A., \& Rodin, I. A. (2019). Sravnenie kinetiki razlichnykh variantov iskusstvennogo stareniia rukopisnykh shtrikhov metodom vysokoeffektivnoi zhidkostnoi khromatografii $s$ mass-spektrometricheskim detektirovaniem. Analitika i kontrol, 23 (1), 84-95. [in Russian]. DOI: http://dx.doi.org/10.15826/analitika.2019.23.1.003.

Batygina, N. A., Bezhanishvili, G. S., Orekhova, M. V., \& Trosman, E. A. (1993). Ustanovlenie fakta nesootvetstviia vozrasta rukopisnykh zapisei, vypolnennykh sharikovymi ruchkami, date, ukazannoi v dokumente. Ekspertnaia tekhnika, 122, 70-92 [in Russian].

Balreira, D. G., Filho, D. M., \& Walter, M. (2020). Assessing similarity in handwritten texts. Pattern Recognition Letters, $138,447-454$. DOI: https://doi.org/10.1016/j.patrec.2020.08.011.

Bentam, I. (1876). O sudebnykh dokazatelstvakh: traktat (po izd. Diumana; per. s fr. I. Goronovichem). Kiev: Tip. M. P. Fritca. $421 \mathrm{s.}$

Bezhanishvili, G. S., Batygina, H. A., \& Trosman, E. A. (1998). O vozmozhnosti opredeleniia vozrasta ottiskov pechatei i shtampov po soderzhaniiu v shtrikhakh letuchikh komponentov. Ekspertnaia tekhnika, 126, 31-51 [in Russian].

Biriukov, V. V., Kovalenko, V. V., Biriukova, T. P., \& Kovalov, K. M. (2007). Kryminalistychne dokumentoznavstvo: prakt. posib. (za zah. red. V. V. Biriukova). Kyiv: Vyd. Palyvoda A. V. 332 s. [in Ukrainian].

Bocheliuk, V., Panov, M., \& Zaitseva, V. (2019). Veryfikatsiia psykhodiahnostychnykh mozhlyvostei rukopysnykh tekstiv. Psycholinguistics, 26 (1), 51-82 [in Ukrainian]. DOI: https://doi.org/10.31470/2309-1797-2019-26-1-51-82.

Brunelle, R. L., \& Reed, R. W. (1984). Forensic Examination of Ink and Paper. Charles C Thomas: Springfield, IL. 302 p. Braichevskaia, E. Iu., \& Ziuskin, N. M. (1967). Osmotr dokumentov: metod. posobie. Kiev: KNIISE. 32 s. [in Russian].

Bügler, J. H., Buchner, H., \& Dallmayer, A. (2008). Age Determination of Ballpoint Pen Ink by Thermal Desorption and Gas ChromatographyMass Spectrometry. Journal of Forensic Sciences, 53 (4), 982-988. DOI: https://doi.org/10.1111/j.1556-4029.2008.00745.x.

Burinskii, E. F. (1903). Sudebnaia ekspertiza dokumentov, proizvodstvo ee i polzovanie eiu: posobie dlia gg. sudei, sudebnykh sledovatelei, litc prokurorskogo nadzora, poverennykh, zashchitnikov, sudebnykh vrachei i graficheskikh ekspertov. Sankt-Peterburg: Tipografiia Sankt-Peterburgskogo tovarishchestva pechatnogo i izdatelskogo dela «Trud». VI, [2], 352 s., 16 l. il.: il. [in Russian].

Cantu, A. A. (1995a). A Sketch of Analytical Methods for Document Dating. Part 1. The Static Approach Determing Age Independent Analytical Profiles. Int. Journal of Forensic Documents Examiners, 1 (1), 40-50. 
Cantu, A. A. (1995b). A Sketch of Analytical Methods for Document Dating. Part II. The Dinamic Approach Determing Age Dependent Analytical Profiles. Retrieved from https://www.researchgate.net/publication/265031776.

Digital Technology: the Document Examiner's Friend and Foe. (2006). The Hague, The Netherlands, 27-30 September. Retrieved from https://manualzz.com/doc/39275025/meeting-programme---college-of-engineering.

Dmytrenko, A., \& Zakhariiash, L. (2004). Osnovy pocherkoznavstva. Kyiv: Dmytrenko M. 63 s.

Eisman, A. A. (1947). Novaia tekhnika usileniia kontrastov v sudebno-issledovatelskoi fotografii. Sovetskoe gosudarstvo $i$ pravo, 9, 84-88 [in Russian].

Ellen, D., Day, S., \& Davies, C. (2018). Scientific Examination of Documents: Methods and Techniques (4th ed.). CRC Press. DOI: https://doi.org/10.4324/9780429491917.

EL-Sabbah, M. M. B., Gomaa, A. Z., El-Hefny, D. E., \& Al-Hawary, A. S. (2019). Dating the Ballpoint Pen Inks Using Gas Chromatography-Mass Spectrometry Technique. Egyptian Journal of Chemistry, 62 (3), 385-400. DOI: https://doi.org/10.21608/ejchem.2018.4812.1427.

Filipenko, N. Ye. (2020). Napriamky udoskonalennia naukovo-metodychnoho zabezpechennia kryminolohichnoi diialnosti sudovo-ekspertnykh ustanov Ukrainy. Pravo.ua, 2, 130-137 [in Ukrainian]. DOI: https://doi.org/10.32782/LAW.2020.1.18.

Gatov, M.Z. (1975). Tekhnicheskoe issledovanie dokumentov putem fotografirovaniia v pole tokov vysokoi chastoty. V pomoshch ekspertam. M.: VNIISE MIu SSSR [in Russian].

Grechukha, N. M., Gorshkova, K. O., Panov, M. S., Tumkin, I. I., Kirillova, E. O., Lukianov, V. V., Kirillova, N. P., \& Kochemirovsky, V. A. (2017). Analysis of the Aging Processes of Writing Ink: Raman Spectroscopy versus Gas Chromatography Aspects. Appl. Sci., 7 (10), 991. DOI: https://doi.org/10.3390/app7100991.

Gross, G. (1930). Rukovodstvo k rassledovaniiu prestuplenii (perevod s 6-go nem. izd., pererab. i dop. I. N. Iakimovym). M.: Izdatelstvo NKVD RSFSR. 144 s. [in Russian].

Gulina, E. G. (2007). Problema ustanovleniia sroka davnosti izgotovleniia dokumenta metodami pocherkovedcheskoi ekspertizy. Sudebnaia ekspertiza: didaktika, teoriia, praktika: sbornik nauchnykh trudov. M.: Mosk. un-t MVD Rossii, 3, 68-76 [in Russian].

Gulina, E. G. (2017). Metodika ustanovleniia vremeni vypolneniia podpisi v dokumente metodami sudebno-pocherkovedcheskoi ekspertizy: ucheb. posobie. M.: Entciklopediia Sudebnoi Ekspertizy. 42 s., 17 ill. [in Russian].

Hamasaki, N., Nakamura, K., Nitta, N., \& Babaguchi, N. (2019). Discrimination between Handwritten and Computer-Generated Texts using a Distribution of Patch-Wise Font Features. Asia-Pacific Signal and Information Processing Association Annual Summit and Conference (APSIPA ASC), Lanzhou, China, pp. 1665-1671.

DOI: https://doi.org/10.1109/APSIPAASC47483.2019.9023197.

Honcharenko, V. H., \& Hora, I. V. (Red.). (2015). Ekspertyzy u sudochynstvi Ukrainy. Kyiv: Yurinkom Inter. 504 s. [in Ukrainian].

Iarovenko, V. V., \& Atanova, K. A. (2013). Kriminalisticheskaia ekspertiza poddelki. Iuridicheskie issledovaniia, 3, 318-329 [in Russian]. DOI: https://doi.org/10.7256/2305-9699.2013.3.612.

Ishchenko, A. V. (2003). Metodolohichni problemy kryminalistychnykh naukovykh doslidzhen: monohrafiia (za red. I. P. Krasiuka). Kyiv: NAVSU. 359 s. [in Ukrainian].

Kasimova, S. Sh. (1958). Opredelenie vozrasta dokumenta (Iz praktiki kriminalisticheskikh issledovanii). M.: Gosiurizdat. 78 s. [in Russian].

Kelly, J. S., \& Angel, M. (Eds.). (2020). Forensic Document Examination in the 21st Century (1st ed.). CRC Press. DOI: https://doi.org/10.4324/9780367853587.

Khlivniak, O. M. (2020). Istoriia vynyknennia, rozvytku ta stanovlennia hrafolohichnoi ekspertyzy pysma (sudovoi pocherkoznavchoi ekspertyzy). Molodyi vchenyi, 2 (78), 305-309 [in Ukrainian]. DOI: https://doi.org/10.32839/2304-5809/2020-2-78-66.

Kirlian, V. Kh., \& Kirlian, S. D. (2003a). V mire chudesnykh razriadov. (Izd. 2-e). Krasnodar: Prosveshchenie-Iug [in Russian].

Kirlian, S. D., \& Kirlian, V. Kh. (2003b). Vysokochastotnye razriady v elektricheskom pole kondensatora: fotografirovanie tokami vysokoi chastoty, vysokochastotnaia elektronno-ionnaia optika. Krasnodar: Prosveshchenie-Iug [in Russian].

Kovalov, K. M., Dovbii, O. O., Hres, O. V., \& Bychkov, A. S. (2020). Mozhlyvosti zastosuvannia metodu raman-spektroskopii pid chas vyrishennia aktualnykh pytan tekhnichnoi ekspertyzy dokumentiv. Kryminalistychnyi visnyk, 2 (34), 47-56 [in Ukrainian]. DOI: https://doi.org/10.37025/1992-4437/2020-34-2-47.

Kovalov, K. M., \& Kovalenko, V. V. (Uklad.). (2009). Metodyka tekhnichnoi ekspertyzy vidbytkiv pechatok i shtampiv. Kyiv: DNDEKTs MVS, 19 s. [in Ukrainian].

Krylov, I. F. (1963). Sudebnaia ekspertiza v ugolovnom protcesse. L.: Izd-vo Leningr. un-ta. 213 s. [in Russian].

Krylov, I. F. (1980). V mire kriminalistiki. L.: Izd-vo Leningr. un-ta. 278 s. [in Russian].

Krylov, I. F. (1987). Byli i legendy kriminalistiki. L.: Izd-vo Leningr. un-ta. 215 s. [in Russian].

Krylov, I. F. (2020). Razvitie ekspertizy dokumentov (fragmenty). Vestnik Universiteta imeni O. E. Kutafina (MGIuA), 6 (70), 164-173. Vziato iz https://cyberleninka.ru/article/n/razvitie-ekspertizy-dokumentov-fragmenty [in Russian].

Lisichenko, V. K. (1960). Kriminalisticheskie issledovanie veshchestvennykh dokazatelstv metodami osnovannymi na primenenii 
radiatcionnykh izotopov. (Avtoref. kand. iurid. nauk). Kievskaia vysshaia shkola USSR, Kiev. 43 s. [in Russian].

Lisichenko, V. K., \& Lipovskii, V. V. (1990). Ispravlennomu ne verit. Kiev: Lybid. 125 s. [in Russian].

Lokar, E. (1941). Rukovodstvo po kriminalistike (pod red. S. P. Mitricheva; perevod S. V. Poznysheva \& N. V. Terzieva). M.: Iurizdat NKIu SSSR. $544 \mathrm{~s}$. [in Russian].

Melenevska, Z. S., Svoboda, Ye. Yu., \& Shabotenko, A. I. (2007). Sudovo-pocherkoznavcha ekspertyza: navch.-metod. posib. (za zah. red. I. P. Krasiuka). Kyiv: Ukrainskyi tsentr dukhovnoi kultury. 280 s. [in Ukrainian].

Métayer, C. (1990). De l'École au Palais de Justice: L'Itinéraire Singulier des Maîtres Écrivains de Paris (XVIe-XVIIIe Siècles). Annales. Histoire, Sciences Sociales, 45 (5), 1217-1237.

DOI: https://doi.org/10.3406/ahess.1990.278899.

Mironovsky, L. A., Nikitin, A. V., Reshetnikova, N. N., \& Soloviev, N. V. (2018). Graphological Analysis and Identification of Handwritten Texts. In: Favorskaya, M., \& Jain, L. (Eds.). Computer Vision in Control Systems-4. Intelligent Systems Reference Library, vol. 136. Springer, Cham.

DOI: https://doi.org/10.1007/978-3-319-67994-5_2.

Mitrichev, S. P. (1939). Kriminalisticheskia ekspertiza. (Dis. kand. iurid. nauk). M. [in Russian].

Motria, S. I. (2005). Ustanovlenie davnosti (vremeni) vypolneniia podpisei s primeneniem traditcionnykh kriminalisticheskikh metodov: metod. rek. M. [in Russian].

Nikolaev, S. A. (2018). Ekspertiza dokumentov kolorimetricheskim metodom. Politekhnicheskii molodezhnyi zhurnal, 3 (20) [in Russian]. DOI: https://doi.org/10.18698/2541-8009-2018-03-273.

Osborn, A. S. (1932). Tekhnika issledovaniia dokumentov (per. s nem. S. M. Potapova). M.: Gos. izd-vo «Sovetskoe zakonodatelstvo». XI, 198 s. [in Russian].

Palii, V. M. (1989). Kriminalisticheskoe issledovanie dokumentov, izgotovlennykh na znakopechataiushchikh ustroistvakh. Kiev: RIO MVD USSR. 156 s. [in Russian].

Paul, F. (1900). Handbuch der kriminalistischen Photographie fu r Beamte der Gerichte, der Staatsanwaltschaften und der Sicherheitsbehorden. Berlin. 93 s.

Peredrii, O. (2020). Osoblyvosti ekspertyzy starovynnykh knyh. Tovaroznavchyi visnyk, 1 (13), 196-205 [in Ukrainian]. DOI: https://doi.org/10.36910/6775-2310-5283-2020-13-16.

Piliukov, Yu. (2017). Systema identyfikatsiinykh oznak pocherku, mozhlyvosti yii udoskonalennia pry provedenni pocherkoznavchoi ekspertyzy pidpysiv. Aktualni problemy pravoznavstva, 4 (12), 257-262 [in Ukrainian].

Potapov, S. M. (1932). Predislovie. V Osborn, A. S., Tekhnika issledovaniia dokumentov (per. s nem. S. M. Potapova) (s. VIIXI). M.: Gos. izd-vo «Sovetskoe zakonodatelstvo» [in Russian].

Pyrih, I. V. (2011). Teoretychni osnovy ekspertnoi diialnosti orhaniv vnutrishnikh sprav: monohrafiia. Dnipropetrovsk: Dniprop. derzh. un-t vnutr. sprav; Lira LTD. 312 s. [in Ukrainian].

Sahare, P., \& Dhok, S. B. (2019). Separation of Machine-Printed and Handwritten Texts in Noisy Documents using Wavelet Transform. IETE Technical Review, 36 (4), 341-361. DOI: https://doi.org/10.1080/02564602.2018.1475266.

Saparov, A. Iu. (2018). Vosstanovlenie posledovatelnosti zapisi v skanirovannykh rukopisnykh tekstakh. Vestnik Udmurtskogo universiteta. Matematika. Mekhanika. Kompiuternye nauki, 28 (4), 595-610 [in Russian]. DOI: https://doi.org/10.20537/vm180411.

Sezonov, V. S. (2020). Henezys kryminalistychnoho doslidzhennia dokumentiv yak haluzi kryminalistychnoi tekhniky. Pravo i bezpeka, 2 (77), 133-140 [in Ukrainian]. DOI: https://doi.org/10.32631/pb.2020.2.18.

Shcherbakovskyi, M. H. (2016). Teoretyko-metodolohichni ta prakseolohichni zasady sudovykh ekspertyz u kryminalnomu protsesi. (Avtoref. dys. d-ra yuryd. nauk). Kharkivkyi natsionalnyi universytet vnutrishnikh sprav, Kharkiv. 40 s. [in Ukrainian].

Skoromnikova, O. A., Iurova, R. A., \& Stepanenko, E. A. (2018). Aktualnye problemy primeneniia metodiki «Opredelenie davnosti vypolneniia rekvizitov v dokumentakh po otnositelnomu soderzhaniiu v shtrikhakh letuchikh rastvoritelei». Teoriia i praktika sudebnoi ekspertizy, 13 (3), 128-131 [in Russian]. DOI: https://doi.org/10.30764/1819-2785-2018-13-3-128-131.

Stewart, L. (1985). Ballpoint Ink Age Determination by Volatile Component Comparison - A reliminary Study. Journal of Forensic Sciences, 30 (2), 405-411. DOI: https://doi.org/10.1520/JFS11819J.

Stratonov, S. Yu. (2019). Poniattia ekspertyzy vstanovlennia davnosti dokumentu, yii mistse v systemi sudovykh ekspertyz i znachennia u kryminalnomu provadzhenni. Naukovyi visnyk publichnoho ta pryvatnoho prava, 6, 317-321 [in Ukrainian]. DOI: https://doi.org/10.32844/2618-1258.2019.6.55.

Stratonov, S. Yu. (2020a). Obiekty ekspertyzy vstanovlennia davnosti dokumenta. Pravo i suspilstvo, 2 (3), 152-158 [in Ukrainian]. DOI: https://doi.org/10.32842/2078-3736/2020.2-3.24.

Stratonov, S. Yu. (2020b). Teoretychni ta metodychni osnovy ekspertyzy vstanovlennia davnosti dokumenta. (Avtoref. dys. kand. yuryd. nauk). Natsionalna akademiia vnutrishnikh sprav, Kyiv [in Ukrainian]. 
Syniavskyi, V. V., \& Serhieienkova, O. P. (Avt.-uklad.). (2007). Psykholohichnyi slovnyk (red. N. A. Pobirchenko). Kyiv: Naukovyi svit. 274 s. [in Ukrainian].

Tcymbal, A. V. (2013). Kliuchevye aspekty metodicheskikh podkhodov pri ustanovlenii absoliutnogo vremeni vypolneniia rekvizitov dokumentov s ispolzovaniem gazokhromatograficheskogo metoda issledovanii. Kriminalistika $i$ sudebnaia ekspertiza, 58 (1), 256-267. Vziato iz http://nbuv.gov.ua/UJRN/krise_2013_58(1)_34 [in Russian].

Terziev, N. V., \& Eisman, A. A. (1949). Vvedenie v kriminalisticheskoe issledovanie dokumentov. Ch. 1. M.: [b. i.]. 124 s. [in Russian].

Terziev, N. V. (1966). Kriminalisticheskoe issledovanie dokumentov: ucheb. posobie po spetckursu. M.: VIuZI. 54 s. [in Russian].

Toropova, M. V. (2014). Kriminalisticheskaia ekspertiza ustanovleniia otnositelnoi davnosti vypolneniia rekvizitov dokumentov. (Dis. kand. iurid. nauk). Federalnoe gosudarstvennoe biudzhetnoe obrazovatelnoe uchrezhdenie vysshego professionalnogo obrazovaniia «Rossiiskaia akademiia pravosudiia», M. 202 s. [in Russian].

Tregubov, S. N. (1915). Osnovy ugolovnoi tekhniki. Nauchno-tekhnicheskie priemy rassledovaniia prestuplenii: prakticheskoe rukovodstvo dlia sudebnykh deiatelei. M.: Izd. iurid. kn. sklada «Pravo». 334 s. [in Russian].

Uvarova, I. A. (2015). Razvitie i sovremennoe sostoianie sudebnogo pocherkovedeniia. Vestnik Tomskogo gosudarstvennogo universiteta, 395, 160-164 [in Russian].

DOI: https://doi.org/10.17223/15617793/395/27.

Veingart, A. (1912). Ugolovnaia taktika. Rukovodstvo $k$ rassledovaniiu prestuplenii (pod red. V. I. Lebedeva). SPb.: Vestnik politcii. 270 s. [in Russian].

Yudina, I. V. (2018). Aktualni pytannia kryminalistychnoho doslidzhennia dokumentiv zi zminenym pervynnym zmistom. Kryminalistychnyi visnyk, 2 (30), 78-91 [in Ukrainian]. DOI: https://doi.org/10.37025/1992-4437/2018-30-2-78.

Zavattaro, D., Quarta, G., D’Elia, M., \& Calcagnile, L. (2007). Recent documents dating: an approach using radiocarbon techniques. Forensic Sci Int, 167 (2-3), 160-162.

DOI: https://doi.org/10.1016/j.forsciint.2006.06.060.

Zhizhilenko, A. A. (1900). Podlog dokumentov: Istoriko-dogmaticheskoe izsledovanie. S.-Peterburg: Nevskaia tipografiia. 746 s. [in Russian].

Ziuskin, N. M., \& Kirichinskii, B. R. (Red.). (1962). Fotograficheskie i fizicheskie metody issledovaniia veshchestvennykh dokazatelstv: posob. dlia ekspertov, rabotnikov organov doznaniia, prokuratury i suda. M.: Iurid. lit. 542 s. [in Russian].

\section{Список використаних джерел}

Adhikari, G., Roy, S., Dasgupta, T., \& Pradhan, T. (2018). A Novel Technique for Unwarping Curved Handwritten Texts Using Mathematical Morphology and Piecewise Affine Transformation. 2018 9th International Conference on Computing, Communication and Networking Technologies (ICCCNT), 1-7. DOI: https://doi.org/10.1109/ICCCNT.2018.8493881.

Aginsky, V. N. (1994). Determination of the age of ballpoint pen ink by gas and densitometric thin-layer chromatography. Journal of Chromatography A, 678, 119-125. DOI: https://doi.org/10.1016/0021-9673(94)87081-0.

Aginsky, V. N. (1996). Dating and Characterizing Writing, Stamp Pad and Jet Printer Inks by Gas Chromatography/Mass Spectrometry. Int. Journal of Forensic Documents Examiners, 2 (3), 103-116.

Агинский, В. Н. (1997). Установление давности выполнения штрихов рукописных текстов: метод. рекомендации. М.: ЭКЦ МВД России. 6, [3] с.

Амеліна, А. С., \& Кужільна, А. Б. (2019). Огляд документів при розслідуванні злочинів у сфері оподаткування. Юридичний науковий електронний журнал, 6, 362-365. DOI: https://doi.org/10.32782/2524-0374/2019-6/86.

Аубакиров, А. Ф. (1965). Использование эффекта высокочастотного искрового разряда при техническом исследовании документов. Проблемы криминалистики и судебной экспертизы. Алма-Ата, 152-154.

Байгильдиева, Д. И. (2019). Хромато-масс-спектрометрический анализ состава рукописных штрихов при естественном и искусственном старении бумажных документов. (Автореф. дис. канд. хим. наук). Московский государственный университет имени М. В. Ломоносова, М. 26 с.

Байгильдиева, Д. И., Байгильдиев, Т. М., Шпигун, О. А., \& Родин, И. А. (2019). Сравнение кинетики различных вариантов искусственного старения рукописных штрихов методом высокоэффективной жидкостной хроматографии с масс-спектрометрическим детектированием. Аналитика и контроль, 23 (1), 84-95. DOI: http://dx.doi.org/10.15826/analitika.2019.23.1.003.

Balreira, D. G., Filho, D. M., \& Walter, M. (2020). Assessing similarity in handwritten texts. Pattern Recognition Letters, $138,447-454$.

DOI: https://doi.org/10.1016/j.patrec.2020.08.011.

Батыгина, Н. А., Бежанишвили, Г. С., Орехова, М. В., \& Тросман, Э. А. (1993). Установление факта несоответствия возраста рукописных записей, выполненных шариковыми ручками, дате, указанной в документе. Экспертная техника, 122, 70-92. 
Бентам, И. (1876). О судебных доказательствах: трактат (по изд. Дюмана; пер. с фр. И. Гороновичем). Киев: Тип. М. П. Фрица. 421 с.

Бежанишвили, Г. С., Батыгина, Н. А., \& Тросман, Э. А. (1998). О возможности определения возраста оттисков печатей и штампов по содержанию в штрихах летучих компонентов. Экспертная техника, 126, 31-51.

Бірюков, В. В., Коваленко, В. В., Бірюкова, Т. П., \& Ковальов, К. М. (2007). Криміналістичне документознавство: практ. посіб. (за заг. ред. В. В. Бірюкова). Київ: Вид. Паливода А. В. 332 с.

Бочелюк, В., Панов, М., \& Зайцева, В. (2019). Верифікація психодіагностичних можливостей рукописних текстів. Psycholinguistics, 26 (1), 51-82.

DOI: https://doi.org/10.31470/2309-1797-2019-26-1-51-82.

Brunelle, R. L., \& Reed, R. W. (1984). Forensic Examination of Ink and Paper. Charles C Thomas: Springfield, IL. 302 p.

Брайчевская, Е. Ю., \& Зюскин, Н. М. (1967). Осмотр документов: метод. пособие. Киев: КНИИСЭ. 32 с.

Bügler, J. H., Buchner, H., \& Dallmayer, A. (2008). Age Determination of Ballpoint Pen Ink by Thermal Desorption and Gas ChromatographyMass Spectrometry. Journal of Forensic Sciences, 53 (4), 982-988.

DOI: https://doi.org/10.1111/j.1556-4029.2008.00745.x.

Буринский, Е. Ф. (1903). Судебная экспертиза документов, производство ее и пользование ею: пособие для гг. судей, судебных следователей, лиц прокурорского надзора, поверенных, защитников, судебных врачей и графических экспертов. Санкт-Петербург: Типография Санкт-Петербургского товарищества печатного и издательского дела «Труд». VI, [2], 352 с., 16 л. ил: ил.

Cantu, A. A. (1995a). A Sketch of Analytical Methods for Document Dating. Part 1. The Static Approach Determing Age Independent Analytical Profiles. Int. Journal of Forensic Documents Examiners, 1 (1), 40-50.

Cantu, A. A. (1995b). A Sketch of Analytical Methods for Document Dating. Part II. The Dinamic Approach Determing Age Dependent Analytical Profiles. Retrieved from https://www.researchgate.net/publication/265031776.

Digital Technology: the Document Examiner's Friend and Foe. (2006). The Hague, The Netherlands, 27-30 September. Retrieved from https://manualzz.com/doc/39275025/meeting-programme---college-of-engineering.

Дмитренко, А., \& Захаріяш, Л. (2004). Основи почеркознавства. Київ: Дмитренко М. 63 с.

Эйсман, А. А. (1947). Новая техника усиления контрастов в судебно-исследовательской фотографии. Советское государство и право, 9, 84-88.

Ellen, D., Day, S., \& Davies, C. (2018). Scientific Examination of Documents: Methods and Techniques (4th ed.). CRC Press. DOI: https://doi.org/10.4324/9780429491917.

EL-Sabbah, M. M. B., Gomaa, A. Z., El-Hefny, D. E., \& Al-Hawary, A. S. (2019). Dating the Ballpoint Pen Inks Using Gas Chromatography-Mass Spectrometry Technique. Egyptian Journal of Chemistry, 62 (3), 385-400. DOI: https://doi.org/10.21608/ejchem.2018.4812.1427.

Філіпенко, Н. Є. (2020). Напрямки удосконалення науково-методичного забезпечення кримінологічної діяльності судово-експертних установ України. Право.иа, 2, 130-137. DOI: https://doi.org/10.32782/LAW.2020.1.18.

Гатов, М. 3. (1975). Техническое исследование документов путем фотографирования в поле токов высокой частоты. В помощь экспертам. М.: ВНИИСЭ МЮ СССР.

Grechukha, N. M., Gorshkova, K. O., Panov, M. S., Tumkin, I. I., Kirillova, E. O., Lukianov, V. V., Kirillova, N. P., \& Kochemirovsky, V. A. (2017). Analysis of the Aging Processes of Writing Ink: Raman Spectroscopy versus Gas Chromatography Aspects. Appl. Sci., 7 (10), 991. DOI: https://doi.org/10.3390/app7100991.

Гросс, Г. (1930). Руководство к расследованию преступлений (перевод с 6-го нем. изд., перераб. и доп. И. Н. Якимовым). М.: Издательство НКВД РСФСР. 144 с.

Гулина, Е. Г. (2007). Проблема установления срока давности изготовления документа методами почерковедческой экспертизы. Судебная экспертиза: дидактика, теория, практика: сборник научных трудов. М.: Моск. ун-т МВД России, 3, 68-76.

Гулина, Е. Г. (2017). Методика установления времени выполнения подписи в документе методами судебно-почерковедческой экспертизы: учеб. пособие. М.: Энциклопедия Судебной Экспертизы. 42 с., 17 илл.

Hamasaki, N., Nakamura, K., Nitta, N., \& Babaguchi, N. (2019). Discrimination between Handwritten and ComputerGenerated Texts using a Distribution of Patch-Wise Font Features. Asia-Pacific Signal and Information Processing Association Annual Summit and Conference (APSIPA ASC), Lanzhou, China, pp. 1665-1671. DOI: https://doi.org/10.1109/APSIPAASC47483.2019.9023197.

Гончаренко, В. Г., \& Гора, І. В. (Ред.). (2015). Експертизи у судочинстві України. Київ: Юрінком Інтер. 504 с.

Яровенко, В. В., \& Атанова, К. А. (2013). Криминалистическая экспертиза подделки. Юридические исследования, 3 , 318-329.

DOI: https://doi.org/10.7256/2305-9699.2013.3.612.

Іщенко, А. В. (2003). Методологічні проблеми криміналістичних наукових досліджень: монографія (за ред. I. П. Красюка). Київ: НАВСУ. 359 с.

Касимова, С. Ш. (1958). Определение возраста документа (Из практики криминалистических исследований). М.: Госюриздат. $78 \mathrm{c}$.

Kelly, J. S., \& Angel, M. (Eds.). (2021). Forensic Document Examination in the 21st Century (1st ed.). CRC Press. 
DOI: https://doi.org/10.4324/9780367853587.

Хлівняк, О. М. (2020). Історія виникнення, розвитку та становлення графологічної експертизи письма (судової почеркознавчої експертизи). Молодий вчений, 2 (78), 305-309.

DOI: https://doi.org/10.32839/2304-5809/2020-2-78-66.

Кирлиан, В. Х., \& Кирлиан, С. Д. (2003а). В мире чудесньхх разрядов. (Изд. 2-е). Краснодар: Просвещение-Юг.

Кирлиан, С. Д., \& Кирлиан, В. Х. (2003b). Высокочастотные разряды в электрическом поле конденсатора: фотографирование токами высокой частоты, высокочастотная электронно-ионная оптика. Краснодар: Просвещение-Юг.

Ковальов, К. М., Довбій, О. О., Гресь, О. В., \& Бичков, А. С. (2020). Можливості застосування методу раман-спектроскопії під час вирішення актуальних питань технічної експертизи документів. Криміналістичний вісник, 2 (34), 47-56.

DOI: https://doi.org/10.37025/1992-4437/2020-34-2-47.

Ковальов, К. М., \& Коваленко, В. В. (Уклад.). (2009). Методика технічної експертизи відбитків печаток і штампів. Київ: ДНДЕКЦ МВС, 19 с.

Крылов, И. Ф. (1963). Судебная експертиза в уголовном проиессе. Л.: Изд-во Ленингр. ун-та. 213 с.

Крылов, И. Ф. (1980). В мире криминалистики. Л.: Изд-во Ленингр. ун-та. 278 с.

Крылов, И. Ф. (1987). Были и легенды криминалистики. Л.: Изд-во Ленингр. ун-та. 215 с.

Крылов, И. Ф. (2020). Развитие экспертизы документов (фрагменты). Вестник Университета имени О. Е. Кутафина (МГЮА), 6 (70), 164-173. Взято из https://cyberleninka.ru/article/n/razvitie-ekspertizy-dokumentov-fragmenty.

Лисиченко, В. К. (1960). Криминалистические исследование вещественных доказательств методами основанными на применении радиационных изотопов. (Автореф. канд. юрид. наук). Киевская высшая школа УССР, Киев. 43 с.

Лисиченко, В. К., \& Липовский, В. В. (1990). Исправленному не верить. Киев: Лыбидь. 125 с.

Локар, Э. (1941). Руководство по криминалистике (под ред. С. П. Митричева; перевод С. В. Познышева \& Н. В. Терзиева). М.: Юриздат НКЮ СССР. 544 с.

Меленевська, 3. С., Свобода, Є. Ю., \& Шаботенко, А. І. (2007). Судово-почеркознавча експертиза: навч.-метод. посіб. (за заг. ред. І. П. Красюка). Київ: Український центр духовної культури. 280 с.

Métayer, C. (1990). De l'École au Palais de Justice: L'Itinéraire Singulier des Maîtres Écrivains de Paris (XVIe-XVIIIe Siècles). Annales. Histoire, Sciences Sociales, 45 (5), 1217-1237.

DOI: https://doi.org/10.3406/ahess.1990.278899.

Mironovsky, L. A., Nikitin, A. V., Reshetnikova, N. N., \& Soloviev, N. V. (2018). Graphological Analysis and Identification of Handwritten Texts. In: Favorskaya, M., \& Jain, L. (Eds.). Computer Vision in Control Systems-4. Intelligent Systems Reference Library, vol. 136. Springer, Cham.

DOI: https://doi.org/10.1007/978-3-319-67994-5_2.

Митричев, С. П. (1939). Криминалистическя экспертиза. (Дис. канд. юрид. наук). М.

Мотря, С. И. (2005). Установление давности (времени) выполнения подписей с применением традиционных криминалистических методов: метод. рек. М.

Николаев, С. А. (2018). Экспертиза документов колориметрическим методом. Политехнический молодежный журнал, 3 (20).

DOI: https://doi.org/10.18698/2541-8009-2018-03-273.

Осборн, А. С. (1932). Техника исследования документов (пер. с нем. С. М. Потапова). М.: Гос. изд-во «Советское законодательство». XI, 198 с.

Палий, В. М. (1989). Криминалистическое исследование документов, изготовленньх на знакопечатающих устройствах. Киев: РИО МВД УССР. 156 с.

Paul, F. (1900). Handbuch der kriminalistischen Photographie fu r Beamte der Gerichte, der Staatsanwaltschaften und der Sicherheitsbehorden. Berlin. $93 \mathrm{s.}$

Передрій, О. (2020). Особливості експертизи старовинних книг. Товарознавчий вісник, 1 (13), $196-205$. DOI: https://doi.org/10.36910/6775-2310-5283-2020-13-16.

Пілюков, Ю. (2017). Система ідентифікаційних ознак почерку, можливості ії удосконалення при проведенні почеркознавчої експертизи підписів. Актуальні проблеми правознавства, 4 (12), 257-262.

Потапов, С. М. (1932). Предисловие. В Осборн, А. С., Техника исследования документов (пер. с нем. С. М. Потапова) (с. VII-XI). М.: Гос. изд-во «Советское законодательство».

Пиріг, І. В. (2011). Теоретичні основи експертної діяльності органів внутрішніх справ: монографія. Дніпропетровськ: Дніпроп. держ. ун-т внутр. справ; Ліра ЛТД. 312 с.

Sahare, P., \& Dhok, S. B. (2019). Separation of Machine-Printed and Handwritten Texts in Noisy Documents using Wavelet Transform. IETE Technical Review, 36 (4), 341-361. DOI: https://doi.org/10.1080/02564602.2018.1475266.

Сапаров, А. Ю. (2018). Восстановление последовательности записи в сканированных рукописных текстах. Вестник Удмуртского университета. Математика. Механика. Компьютерные науки, 28 (4), 595-610. DOI: https://doi.org/10.20537/vm180411.

Сезонов, В. С. (2020). Генезис криміналістичного дослідження документів як галузі криміналістичної техніки. Право і безпека, 2 (77), 133-140. 
DOI: https://doi.org/10.32631/pb.2020.2.18.

Щербаковський, М. Г. (2016). Теоретико-методологічні та праксеологічні засади судових експертиз у кримінальному процесі. (Автореф. дис. д-ра юрид. наук). Харківький національний університет внутрішніх справ, Харків. $40 \mathrm{c}$.

Скоромникова, О. А., Юрова, Р. А., \& Степаненко, Е. А. (2018). Актуальные проблемы применения методики «Определение давности выполнения реквизитов в документах по относительному содержанию в штрихах летучих растворителей». Теория и практика судебной экспертизы, 13 (3), 128-131. DOI: https://doi.org/10.30764/1819-2785-2018-13-3-128-131.

Stewart, L. (1985). Ballpoint Ink Age Determination by Volatile Component Comparison - A Preliminary Study. Journal of Forensic Sciences, 30 (2), 405-411. DOI: https://doi.org/10.1520/JFS11819J.

Стратонов, С. Ю. (2019). Поняття експертизи встановлення давності документу, іï місце в системі судових експертиз і значення у кримінальному провадженні. Науковий вісник публічного та приватного права, 6, 317-321. DOI: https://doi.org/10.32844/2618-1258.2019.6.55.

Стратонов, С. Ю. (2020а). Об’єкти експертизи встановлення давності документа. Право і суспільство, 2 (3), 152158.

DOI: https://doi.org/10.32842/2078-3736/2020.2-3.24.

Стратонов, С. Ю. (2020b). Теоретичні та методичні основи експертизи встановлення давності документа. (Автореф. дис. канд. юрид. наук). Національна академія внутрішніх справ, Київ.

Синявський, В. В., \& Сергєєнкова, О. П. (Авт.-уклад.). (2007). Психологічний словник (ред. Н. А. Побірченко). Київ: Науковий світ. 274 с.

Цымбал, А. В. (2013). Ключевые аспекты методических подходов при установлении абсолютного времени выполнения реквизитов документов с использованием газохроматографического метода исследований. Криминалистика и судебная экспертиза, 58 (1), 256-267. Взято из http://nbuv.gov.ua/UJRN/krise_2013_58(1)__34.

Терзиев, Н. В., \& Эйсман, А. А. (1949). Введение в криминалистическое исследование документов. Ч. 1. М.: [б. и.]. $124 \mathrm{c}$.

Терзиев, Н. В. (1966). Криминалистическое исследование документов: учеб. пособие по спецкурсу. М.: ВЮЗИ. 54 с.

Торопова, М. В. (2014). Криминалистическая экспертиза установления относительной давности выполнения реквизитов документов. (Дис. канд. юрид. наук). Федеральное государственное бюджетное образовательное учреждение высшего профессионального образования «Российская академия правосудия», М. 202 с.

Трегубов, С. Н. (1915). Основы уголовной техники. Научно-технические приемы расследования преступлений: практическое руководство для судебных деятелей. М.: Изд. юрид. кн. склада «Право». 334 с.

Уварова, И. А. (2015). Развитие и современное состояние судебного почерковедения. Вестник Томского государственного университета, 395, 160-164. DOI: https://doi.org/10.17223/15617793/395/27.

Вейнгарт, А. (1912). Уголовная тактика. Руководство к расследованию преступлений (под ред. В. И. Лебедева). СПб.: Вестник полиции. 270 с.

Юдіна, І. В. (2018). Актуальні питання криміналістичного дослідження документів зі зміненим первинним змістом. Криміналістичний вісник, 2 (30), 78-91. DOI: https://doi.org/10.37025/1992-4437/2018-30-2-78.

Zavattaro, D., Quarta, G., D’Elia, M., \& Calcagnile, L. (2007). Recent documents dating: an approach using radiocarbon techniques. Forensic Sci Int, 167 (2-3), 160-162. DOI: https://doi.org/10.1016/j.forsciint.2006.06.060.

Жижиленко, А. А. (1900). Подлогъ документовъ: Историко-догматическое изследованіе. С.-Петербургъ: Невская типографія. 746 с.

Зюскин, Н. М., \& Киричинский, Б. Р. (Ред.). (1962). Фотографические и физические методы исследования вещественных доказательств: пособ. для экспертов, работников органов дознания, прокуратуры и суда. М.: Юрид. лит. 542 с. 


\author{
K. Kovalov, Deputy Director, \\ State Scientific Research Forensic Centre, \\ MIA of Ukraine, Kyiv, Ukraine \\ ORCID: https://orcid.org/0000-0003-1964-9283
}

\title{
DETERMINATION OF THE AGE OF THE DOCUMENT: HISTORICAL ASPECT AND CURRENT TRENDS
}

\begin{abstract}
The purpose of the article is to identify current trends in the further formation of scientific and methodological principles for determining the age of a document in the context of the main milestones in the development of criminology. Methodology. The reliability of the obtained results and conclusions is ensured by the use of a set of general scientific and special research methods. In particular, with the help of the dialectical method as a general method of cognition the issues of the topic were considered in dynamics. Their interrelation and interdependence were revealed. Through the application of system and historical analysis methods, formal logic, abstraction and analogy, generalization and classification in the context of the main milestones in the development of forensic science, the stages of formation of scientific and methodological principles for determining the age of the document are outlined. The main trends of their improvement are characterized. Perspective directions of expanding the possibilities of forensic examination of documents, in order to determine the age of the document are highlighted. Scientific novelty. An attempt to briefly characterize the current trends in the formation of scientific and methodological principles was made through the prism of history for determining the age of the document in the context of the main milestones in the development of criminology. Conclusions. The stages of the development of forensic records management, the formation of scientific and methodological foundations of the study of documents in order to determine their age are highlighted. They are conventionally designated in the context of the main milestones in the development of forensic science by three large periods: the emergence and formation of the foundations of forensic knowledge (until the end of the 19th century); the formation and development of forensics as a science (late 19th century - late 70 s of the 20th century) differentiation of forensic knowledge and the formation of the foundations of independent scientific disciplines within it (from the end of the 70s of the 20th century). It is emphasized that at the present stage of development of forensic document science research conducted to determine the age of the document is based on a thorough scientific and methodological work on individual details, primarily made of ballpoint pen pastes, stamp inks. Instead, scientific and methodological support for the study of other details and parts of the document requires in-depth study, practical testing, as well as the introduction of an integrated approach and use of special knowledge, various analytical and special methods of forensic examination of documents, including a combination of methods and techniques of forensic handwriting and technical research documents. Perspective directions of expansion of possibilities of forensic examination of documents for the purpose of determination of their age are: deepening of their complexity; using of special knowledge, various analytical and special methods of forensic examination of documents; developing non-destructive methods; automating and computerizing processes of application of methods; algorithmization of research processes.

Keywords: forensic document science; forensic technical examination of documents; forensic handwriting examination; determining the age of the document; scientific and methodological principles for determining the age of the document; research methods; research methodology; integrated approach; specialized knowledge.
\end{abstract}

\author{
К. Н. Ковалев, заместитель директора, \\ Государственный научно-исследовательский \\ экспертно-криминалистический центр \\ МВД Украиньи, г. Киев \\ ORCID: https://orcid.org/0000-0003-1964-9283
}

\section{УСТАНОВЛЕНИЕ ДАВНОСТИ ИЗГОТОВЛЕНИЯ ДОКУМЕНТА: ИСТОРИЧЕСКИЙ АСПЕКТ И СОВРЕМЕННЫЕ ТЕНДЕНЦИИ}

\footnotetext{
Цель статьи - выявить современные тенденции дальнейшего формирования научно-методических основ установления давности изготовления документа в контексте основных вех развития криминалистики. Методология. Достоверность полученных результатов и выводов обеспечена использованием комплекса общенаучных и специальных методов исследования. В частности, с помощью диалектического метода как общего метода познания вопросы темы рассмотрены в динамике, выявлены их взаимосвязь и взаимообусловленность, благодаря применению методов системного и исторического анализа, формальной логики, абстракции и аналогии, обобщения и классификации в контексте основных вех развития криминалистики обозначены этапы формирования научно-методических основ определения давности изготовления документа, охарактеризованы основные тенденции их совершенствования, выделены перспективные направления расширения возможностей судебной экспертизы документов с целью установления давности их изготовления.
} 
Научная новизна. Сделана попытка через призму истории кратко охарактеризовать современные тенденции формирования научно-методических основ установления давности изготовления документа в контексте основных вех развития криминалистики. Bыъоды. Выделены этапы развития криминалистического документоведения, формирования научно-методических основ исследования документов с целью установления давности их изготовления, условно обозначенные в контексте основных вех развития криминалистики тремя большими периодами: возникновение и формирование основ криминалистических знаний (до конца ХІХ в.); становление и развитие криминалистики как науки (конец XIX в. - конец 70-х гг. XX в.); дифференциация криминалистических знаний и формирование в ее рамках основ самостоятельных научных дисциплин (с конца 70-х гг. ХХ в.). Отмечено, что на современном этапе развития криминалистического документоведения исследования, проводимые с целью установления давности изготовления документа, опираются на основательные научно-методические наработки касательно отдельных реквизитов, прежде всего выполненных пастами шариковых ручек, штемпельными красками, при этом научно-методическое обеспечение исследования других реквизитов и частей документа требует углубленного изучения, практической апробации, а также комплексного подхода и использования специальных знаний, различных аналитических и специальных методов криминалистического исследования документов, в частности сочетания методов и методик решения задач судебной почерковедческой экспертизы и технического исследования документов. Выявлены перспективные направления расширения возможностей судебной экспертизы документов с целью установления давности их изготовления, которыми, видимо, являются: углубление их комплексности; использование специальных знаний, различных аналитических и специальных методов криминалистического исследования документов; развитие неразрушающих методов; автоматизация и компьютеризация процессов применения методов; алгоритмизация процессов исследования.

Ключевые слова: криминалистическое документоведение; судебная техническая экспертиза документов; судебная почерковедческая экспертиза; установление давности изготовления документа; научно-методические основы установления давности изготовления документа; методы исследования; методика исследования; комплексный подход; специальные знания. 